\title{
A Study on competitive advantage and risk management of trade between Guangxi and ASEAN-countries
}

\author{
Huo Jun \\ GuangXi Zhuang Autonomous Region Office. \\ SAT \\ Naning, China \\ huojun514@163.com
}

Zhuang Ke

\author{
GuangXi Zhuang Autonomous Region Office. \\ SAT \\ Naning, China \\ zk-12345@163.com \\ Qin Dalei * \\ GuangXi Zhuang Autonomous Region Office. \\ SAT \\ Naning, China \\ 396638155@qq.com
}

\begin{abstract}
The establishment of CAFTA (China-ASEAN Free Trade Area ) and the implementation of the Belt and Road initiative will explore new growth of trade between Guangxi Zhuang Autonomous Region and ASEAN countries. This paper describes the competitive advantages of Guangxi and explains how to avoid competitive risks in the Guangxi-ASEAN trade, from two aspects of trade structure optimization and tax revenue loss. The comparative advantages of Guangxi include trade surplus, product competitiveness. The competitive risks, which come from long-term existence of low end competitive advantages, include trade dependence, export imbalance. Guangxi should increase competitiveness regional trade while reducing risks.
\end{abstract}

\section{Keywords-ASEAN; Trade Competitive; Advantage; Risk}

\section{INTRODUCTION}

With the development of economic globalization, the commercial contract between China and ASEAN countries has more and more frequent. The implementation of "B\&R" strategy provides more opportunities for China in expansion of export trade to ASEAN. As the forward position of China to ASEAN, Guangxi Region should take the full advantage to expand its exports to Southeast-Asia countries. From 2011 to 2015, the significant growth of Guangxi-ASEAN trade volume expands the trade surplus and brings a huge trade competitive advantage with increasing competitive risk [1]. This paper suggests that Guangxi should take effective measures to keep their advantages by managing trade competition risk.

There is not systematic comparative analysis in Guangxi-ASEAN trade competition. However, some relative academic achievements are available for reference. Zheng Guihuan and Wang Shouyang (2005) made an empirical analysis of the welfare effects of tariff reduction. It proves that the benefit of international trading competition is limited in developing areas. The study of Cui Zhiwen and Guo Jing (2015) demonstrated the fact, that there is a positive correlation, based on PVAR model, between horizontal imbalance of VAT distribution and regional economic development. Based on relative date of export rebates, Liao

\footnotetext{
*Corresponding author
}

Ningbin (2014) said the rapid growing amount of small-scale border trade brought considerable potential risks. And Zhang Peifeng (2015) has studied the tax problems in the implementation of The Belt and Road policy from the perspective of the construction of economic zone [2].

\section{GENERAL SITUATION}

Between 2011 and 2015, Guangxi's exportation with ASEAN has the following characteristics.

\section{A. Total amount}

Guangxi's exports to ASEAN countries increased from 45.88 billion dollars to 170.73 billion dollars, Cumulative export amount was 504.07 billion dollars, The average annual growth rate was $67.19 \%$.

\section{B. Key markets}

Vietnam, Indonesia, Singapore were the three largest markets. And Vietnam, which total export amount, was 450.44 billion dollars, accounted for $88.84 \%$ of Guangxi's total export to ASEAN.

\section{Export methods}

The way of Guangxi-ASEAN exportation included small-scale border export, custom special supervised export and export processing. $78 \%$ of export commodities, 392 billion dollars, were exchanged by small-scale border export, and $93 \%$ of them, 365 billion dollars, were sold to Vietnam [3].

\section{Structure of export products}

The main export products were electromechanical equipments, clothes, textiles, agricultural products, which proportion were $33 \%, 28 \%, 13 \%$ and $4 \%$ respectively.

\section{E. Enterprise type}

498.61 billion dollars, above $90 \%$ of total exportation, were traded by private companies. By comparison, the exportation of State-owned enterprise and foreign invested 
enterprises were limited.

\section{EvaluATION}

From the preceding analysis, Guangxi has gained a competitive advantage in trade with ASEAN. In order to evaluate the competitive advantage of Guangxi better, it introduces a new concept, namely, Trade Competitive Index (TCI).

TCI can be formulated as ratio of forex (FX) balance to total forex as given in equation $\mathrm{TCI}=(\mathrm{Xij}-\mathrm{Mij}) /(\mathrm{Xij}+\mathrm{Mij})$. In this equation, " $X$ " means exportation, and " $M$ " means importation. "i" represents a geographic area, such as region or country, and " $\mathrm{j}$ " represents one product. It can be used as a proxy to determine health of foreign trade. The ratio from -1 to 1; Higher ratio being indicative of higher international trade competitiveness. Measurement and evaluation standard of TC index are as follows.

a) The range of $\mathrm{TC}$ value is between minusland minus 0.6 ,then it indicates that there is great competitive disadvantages;

b) The range of TC value is between minus 0.6 and minus 0.3 , then it indicates that there is some competitive disadvantages;

c) The range of $\mathrm{TC}$ value is between minus 0.3 and 0 , then it indicates that there is a little of competitive advantages;

d) The range of $\mathrm{TC}$ value is between 0.3 and 0.6 , then it indicates that there is some competitive advantages;

e) The range of $\mathrm{TC}$ value is between 0.6 and 1 , then it indicates that there is great competitive advantages.

Calculation results: From 2011 to 2015, the TC value of Guangxi trade to ASEAN was $0.41,0.43,0.55,0.58,0.72$, the average value was 0.54 , which was between 0.6 and 0.3 .

In order to reduce location advantage affect trade advantage, we has determined the TC value of the 20 "B\&R" provinces,such as Fujian, Guangdong, Zhejiang, Hainan, Yunnan, Xinjiang, Chongqing, Jiangsu etc.. In the same period, the average TC index of the 20 provinces trade to ASEAN was 0.22 .

We set " $i$ " as Guangxi and " $j$ " as the total import and export commodities of Guangxi-ASEAN, the results of these calculations is summarized in the following table:

TABLE I. TC VALUE OF GuANGX's Trade to ASEAN

\begin{tabular}{|l|l|}
\hline \multicolumn{1}{|c|}{ Year } & \multicolumn{1}{c|}{ TCI of Guangxi to ASEAN } \\
\hline 2011 & 0.41 \\
\hline 2012 & 0.43 \\
\hline 2013 & 0.55 \\
\hline 2014 & 0.58 \\
\hline 2015 & 0.72 \\
\hline Annual Average & 0.54 \\
\hline
\end{tabular}

In order to reduce the impact of location advantage on evaluation results, we also calculated the TCI of other 20 "B\&R" provinces, such as Fujian, Guangdong, Zhejiang, Hainan, Yunnan, Xinjiang, Chongqing and Jiangsu. The average TCI was 0.22 .

Thus, during the recent five years, Guangxi's TCI in the trade of ASEAN has been continuously strengthened annually. On the other hand, the evaluation result of Guangxi's TCI is more than twice the average for other 20 "B\&R" provinces.

\section{ANALYSIS}

The impressive performance of Guangxi's TCI to ASEAN was formed as the result of many aspects, such as trade features, fiscal and tax policies.

\section{A. Trade features}

Leading role of Guangxi and Vietnam's Trade. From 2011 to 2015, Guangxi had a 37 billion trade surpluses in trade with ASEAN, and $85 \%$ of them was generated by their 50.5 billion trades with Vietnam.

Significant proportion of small-scale border trade. Due to the geographical factors and the policy, the amount of small-scale border trade had increased annually.

Private enterprises. Private companies had made great contribution, accounting to $80 \%$ of total, to the trading development.

Labor-intensive product. More than $90 \%$ of the export commodities were labor intensive products

\section{B. Fiscal and taxation policies}

Special border trade financial and taxation policy. There were three major financial and taxation policies applied in Guangxi. Firstly, the tax rebate policy can be used for small border trade export goods, which were RMB-settled by bank transfer, since March 1st, 2010. Secondly, from 2011, customs declaration of small-scale border trade managed by Record verification. Third, local government adopted the incentive policies for the development of border trade.

Tariff reduction of agriculture products. Before the signing of the Agreement of Trade in Goods, China obtained its advantage in trading competition by reducing tariffs on 600 kinds of agricultural and sideline products to ASEAN. Guangxi, as a leading agricultural producer in China, had exported a large amount of agricultural products, accounting for $23 \%$ of total exports

More flexible tax rebate policy. From 2011 to 2015, the cumulative amount of the Guangxi-ASEAN export tax rebates, Which average annual growth rate was $11 \%$, amounted to 6 billion RMB.

\section{RISKS}

The competition risks derived from the competitive advantages are mainly reflected in the following aspects:

\section{A. Low trade revenue}

Export processing was the main trade method in Guangxi 
and the added value of product is relatively lower. From 2011 to 2015, the trade revenue of Guangxi to ASEAN was far below other provinces such as Guangdong, Fujian and Chongqing. In other words, the majority of Guangxi's exports to ASEAN were high-cost and low-income, and it could not be converted to profit growth or stimulated the export enterprise to reform the intrinsic technology progress mechanism and the scale economy.

\section{B. Over-reliance on trade with Vietnam}

Owing to the high dependence on trade with Vietnam, both upstream and downstream products in Guangxi were controlled by economic relation between Chinese and Vietnamese government, and the economic relation was easily influenced by political disputes. Although the recent improvement in ties with Beijing and Hanoi was grounds for cautious optimism, Vietnam had been granted membership of Trans-Pacific Partnership Agreement. Their participation of TPP would be seen as potential political risk, just as the maritime territorial disputes between China and Vietnam.

\section{Limited risk-resistant capacity}

Private companies of Guangxi played a leading role in trade with ASEAN. However, most of the private enterprises could not fight against the risks of international business in South-east Asia. On one hand, these risks, including foreign trade barriers, randomness of decision making, lack of funds, product quality, management problem, were profoundly harmful to the private companies. On the other hand, the fact that the development of Chinese motorcycle enterprises in Vietnam, revealed that cut-throat competition would only be a lose-lose, by of price alternatives.

\section{Problem of small-scale border trade}

Small border trade enterprises exist the following problems: one was easy to obtain import and export qualification, two was the limited trade scale and large mobility; third was no accounting, and its tax was difficult to calculate. In the first half of 2014, for example, in the top 3 side small trade enterprises of Guangxi, their cumulative exports were $\$ 28.4$ billion. However, taxes paid by them were 3853.23 yuan, and they obtained support funds more than 3000 million yuan from central and local government

\section{E. Loss of tax revenue}

The implement of zero tariff treatment to exports to ASEAN and the tax rebates led to that Guangxi in the import and export sectors did not receive any tax revenue. On the contrary, the harm of the tax loss to our national economy was considerable, and some foreign investors took advantage of transfer pricing to evade tax payment and divert profit in Guangxi.

\section{STRATEGIES}

In order to reduce the potential trade risks, Guangxi should take the following measures to optimize the economic structure and reduce the loss of tax revenue.

\section{A. Decoupling the dependency to single trading partner}

We should expand trading areas, improve trade structure, explore new growth areas of trade, and promote trade balance. We should make innovations in our forms of trade, and develop cross-border e-commerce and other modern business models. A service trade support system should be set up to consolidate and expand conventional trade, and efforts to develop modern service trade should be strengthened. We should integrate investment and trade, and promote trade through investment.

\section{B. Increase the additional value of the export goods}

Firstly, the public sector of Guangxi would need to put in place consistent policies to encourage local and international investors to set up relevant industries to process the relevant primary products, thereby adding value and making them export-oriented. Secondly, Guangxi should develop the industry of the municipal agriculture, improve the quality and depth of the agricultural productions, and increase the additional value of the agricultural productions. Thirdly, for the expansion of net income of trade, Guangxi should draw on the experience of Chongqing and Guangdong, adjust the export structure, give priority to the development of processing trade, reduce the consumption of resources and environment and enhance the comprehensive competitiveness of products and added value.

\section{Adjustment of fiscal and taxation policies}

To lessen the impact of tax evasion and to correct fiscal imbalances, Guangxi should adjust its fiscal policies by making their tax systems more progressive and broadening their tax base. Through the improvement of resource allocation efficiency, better promote the development mode transformation and industrial structure adjustment.

\section{Solve the problem of trade and tax competition, through \\ the multilateral coordination mechanism}

Local taxation departments should fully consider the issue of tax and non tax adjustment. In the scope of authority, they could take some flexible measures to properly retain the preferential tax policies for ASEAN trade, and gradually reduce the other effects of the special benefits are not obvious, in order to establish preferential mechanism for the preferential treatment of the industry and the regional preference.

\section{CONCLUSION}

The evaluation of TCI shows that Guangxi has strong competitiveness in trade with ASEAN. However, compared with the advanced provinces, the competitiveness is still limited. Government departments of Guangxi should strengthen research, formulate long-term measures to ensure the trade competitive advantage, control the risk of trade structure and the expansion of the risk of tax loss.

\section{ACKNOWLEDGEMENTS}

First of all, I would like to express my sincere gratitude to all those leaderships and experts, who come from Science Research Institute of SAT, Guangxi Zhuang Autonomous 
Region Office SAT, and Guangxi University of Finance and Economics. Without their concern and support, the completion of this thesis would not have been possible. High tribute shall be paid to all authors of our reference, for their in-depth research and impressive conclusion. And special thanks to Yunnan University of Finance and Economics for their supporting.

\section{REFERENCE}

[1] Q.J. Shang, "Analysis of Tax Incentives for Border trade," Reform and Strategy, 2006, pp. 53-55.

[2] L.J. Zhang, and Z.Y. Zhu, "Analysis of the Impact of China's Tax on Export Trade," International Trade Issues, 2005, pp. 25-29.

[3] G.H. Zheng, and S.Y. Wang, "Welfare Effects of Tariff Reduction and Empirical Analysis," Public Management Journal, 2005, pp. 1-6. 